\title{
Governance within European Space Policy ${ }^{1}$
}

\section{Introduction}

The space policy of the European Union is a multidimensional and long-term planned policy of intertwined processes and political, economic, and social ideas characterized by complex dynamics, taking place in a multipolar international environment. This is an example of a unique European policy because it has been aimed at, implemented with, and planned for the EU Member States, non-EU countries, European space-faring states, space-faring powers as well as countries with growing aspiration in space (Madders, 1997). In this way, the European Union not only carries out political activities in Europe, formulating strategies and objectives on the global level but also provides stimuli for the development of the space services market and European space industry as well as contributes to structural changes in outer space governance, providing space services such as the Galileo satellite navigation signal or Copernicus.

Space assets and services have become strategically important to the European Union since the 1990s, and all EU objectives would not be achieved without access to space. Therefore civil, commercial, security, and defense-related policy objectives are emphasized in the Space Strategy for Europe, understanding that "Europe needs to ensure its freedom of action and autonomy" (European Commission, 2016). Nevertheless the purpose of European space assets, apart from the commercial one, seems unclear, especially when space is becoming a more contested environment than in the $20^{\text {th }}$ century. When traditional competitors, namely space-faring powers, could be easily identified, new actors, both private and public, are launching their spacecraft. Therefore, possible space jams, fragments of space debris, as a results of multiple collisions, are emerging around the globe, in part spurred by the reduced costs of developing and launching satellites. Moreover, growing technical capabilities, both to observe from the orbit, and to interfere with spacecraft call for greater flexibility and agility in policymaking on the European level. This article seeks to advance scientific knowledge of the political processes that determine the nature and the formation of EU experimentalist governance in space. While seeking to build its space regime, the EU also promotes experimentalist modes of governance that it has developed internally in various areas, also in space policy.

1 The article is written within the research project Experimentalist governance in the space policy of the European Union (2019/35/B/HS5/01961) granted by the Polish National Science Centre. 


\section{In the search for a mode of governance within European Space Policy}

In trying to reconstruct what European governance is, Thomas O. Hueglin refers to the concept of a universal project, in which, however, the role played by countries, squeezed between numerous subnational participants and EU regulatory competencies, is becoming less and less important (Hueglin, 1999, p. 251). If we assume that European space policy is nothing more than confirmation of the neo-functional model of European Union development, with the continuous expansion of competencies and growing interdependencies, this area would be relevant for analysis only as another confirmation of the established research model. However, it should be assumed that European space policy contains an inherently political element that should be analyzed in a broader context for two reasons. First, European space policy has been implemented for many years by a separate entity from the European Communities, namely European Space Agency, and therefore the logic of political and industrial integration is characterized by different dynamics from the processes taking place within the Communities, controlled and inspired by both the Member States and the Commission. Thus, when European space policy appeared on the EU agenda, mechanisms of cooperation and coordination of industrial policies developed for over two decades already existed, and the alternative integration model implemented by ESA was connected with the processes taking place within the European Union. The second reason is related to the sociological approach to the analysis of European integration. In the case of ESA, as an entity focused primarily on deepening knowledge about the Universe and operating in different categories and values than the European Communities, the issues of power and prestige were of secondary importance, and as Stacia Zabusky points out, they even disturbed the implementation of ESA's goals (Zabusky, 1995, p. 52). With adherence of the European Union, as initially one of the observers of ESA's activities, and then the most important actor informally defining institutional power through the fact of controlling the budget and having an impact on the direction of development of ESA technology programs means changing the direction of development of European space programs. It also means that as two concepts of integration within the same area overlap, power and governance become more apparent and some of their features become easier to grasp and analyze.

Some authors argue in that most of the analysis regarding the European Union, such issues as power and sovereignty are ignored or excluded, while these concepts are present in the intergovernmental bargain. These elements are also present when the analysis is carried out at the level of individual institutions, individual policies as well as individual cases (Saurugger, 2014, p. 225). Beate Kohler-Koch believes that, from the perspective of European governance theory supporters, "annoying evidence" of "unlimited vitality of national governments" (Kohler-Koch, 1996, p. 364) is visible and power issues should, therefore, be part of the European Union's analysis. The scope of power influence can be described using three variables: level of centralization, functional scope, and territorial scope (Leuffen, Rittberger, Schimmelfennig, 2012, pp. 8-9). In the case of the European Union, this gives a diverse mosaic of influence on political reality, which extends beyond the borders of EU Member States, but also does not mean that the EU institutions gather full political power. However, 
some authors, such as Genschel and Jachtenfuchs, point out that the EU is involved in matters of low political significance and is focused on efficiency, while the Member States focus on ideological issues and redistribution (Genschel, Jachtenfuchs, 2014, p. $3)$. The assumption that the EU system is a system whose purpose is regulation and efficiency is, according to some authors, acceptable from a normative and empirical point of view. First of all, an assumption that efficiency is the norm to be sought and which defines the scope of political actions taken invalidates questions about the democratic deficit of EU institutions (Genschel, Jachtenfuchs, 2014, p. 3). Moreover, the principles of regulation and efficiency are embedded in TFEU concerning the common market, which is created and regulated by EU institutions. The value and slogan to be used to increase efficiency are further and more complete integration.

Integration, according to some authors, depends primarily on preferences, which are considered in three different dimensions. The subjective dimension of preferences allows indicating which participants declare and implement their preferences regarding integration processes. In this group, we can find both European institutions and governments (national and sub-national), civil societies, or private participants who see in the currents of integration the possibility of pursuing economic interests. The second dimension in which preferences should be considered is whether they are exogenous, i.e. not resulting from previous European integration processes or endogenous, and thus being the result of previous actions. The third dimension will be ideological and material preferences related to the perception of the goal of integration as building ideas and identities, or the pursuit of acquiring or expanding resources (Leuffen, Rittberger, Schimmelfennig, 2012, pp. 34-35). It should be emphasized, however, that the aforementioned three dimensions do not appear in the "pure" form and material preferences are accompanied by ideological components. Similarly, it is difficult to identify uniformly exogenous and endogenous preference components. In the case of European space policy, it is so complicated that integration at the European level in this field has been parallel to the integration of the Communities and the European Union. Thus, integration pressure has arisen both within the EU and between ESA member states, and the premises for integration have their source in the same political processes but considered in different fora.

If one analyzes European space policy as a process, then one should refer to the sociological concepts of determining the shape of European integration. Niilo Kauppi argues that EU policy is a social activity that occurs in relation to historically evolving areas of power that contain symbolic and material elements like the institutions of the European Union, various groups and individuals, social representations, and public policies (Kauppi, 2011, p. 151). The EU policy understood in this way puts large social structures and processes at the forefront, assuming that in the European Union there is no direct link between the individual and the policy, since individuals are always members of a certain group (or groups) and perform specific roles. Besides, individual actions are conditioned and targeted through political institutions with both a national (local, parliamentary, and European parliamentary election) and supranational dimension (Kauppi, 2011, pp. 151-152).

Nevertheless, Georgakakis and Rowell point to the "porosity of institutional boundaries" in the European Union, which means that pressure groups have access 
to Eurocrats, which creates relationships between EU institutions and groups of actors involved in creating regulation at the European level (Georgakakis, Rowell, 2013, p. 13). Since this regularity occurs in all areas of activity of EU institutions, this also applies to space policy. However, space policy remains one of the few specific areas in which countries play a much larger role than private entities. Thus, the thesis regarding the discrepant differences between private and public interests (Georgakakis, Rowell, 2013, p. 15), which explains the scope of possible regulations at the European level, refers to space policy, which is conducted in two ways and based on instruments that are not under full EU control. At the same time, the European Commission is the institution that, by providing funding in the space policy budget, becomes a participant shaping public policy at the European level, including ESA member states.

Focusing on the process approach to European space policy makes it possible to refer to political processes in the EU using the perspective of governance. First of all, it is an "antidote to traditional studies of government which, a priori, accept the existence of a hierarchy of power and are primarily focused on politics in the traditional sense. The second reason why any analysis of the EU policies should be separate is that it is still an unfinished project, which is not a state, and therefore also one in which the tools used to analyze the policy of states cannot be properly applied. The third premise and argument for using the governance perspective is the fact that focusing on politics and politics avoids questions related to what integration goal should be achieved in the European Union (Wallace, 2003, p. 1). This argument, however, is quite problematic, because the purely functionalist assumption that political action can be reduced only to analyzing the mid-level, without referring to the ideas, interests, and goals pursued by politics does not bring closer the sense of political action. On the contrary, the claim that at the current stage European politics has an experimental and evolutionary dimension, often appearing in publications related to the European Union (Wallace, 2001), overlooks the real European politics, conducted at different fora.

In addition, the assumption of the possibility of testing the proposed solutions and constant changes in the concept, called evolution, overlooks the fact that evolution is by definition not a planned process, but an accidental, thoughtless, and extremely time-consuming undertaking, which, however, is subordinated to a specific imperative. At the same time, evolution also assumes that a current stage is an imperfect form, without indicating the desired features of the final policy. However, if we assume that the feature of European governance and the European political system is the pursuit of efficiency and responsibility, and this system combines intergovernmental elements, supranational technocracy, and political community, it is evident that there is governance without government (Kohler-Koch, 1999, p. 17). Moreover, some authors argue that just as any constitutional system reaches a point of development where there is no need to change existing rules to achieve stability, the EU is already a mature system (Moravcsik, Schimmelfennig, 2009, p. 84). At the same time, European governance should not be evaluated and analyzed as a one-way transformation, where decisions made are not subject to change and transformation.

Governance refers to the provision of common goods to the political system or ensuring order by creating interaction between different categories of entities and then coordinating their activities (Tömmel, 2009, p. 12). At the same time, governance re- 
fers to both structure and process, where, on the one hand, different ways of coordination (process) are emphasized, and on the other, institutional structures, also shaped in different ways. In turn, Arthur Benz argues that governance is a means of coordination, specific schemes of related structures and processes that imply mechanisms of joint actions (Benz, 2009, p. 28). At the same time, coordinated collective actions are possible without control through rigid rules inscribed in institutions. However, this is not a narrowly understood network of connections, because the effects of governance in the European Union extend far beyond the borders, and this is the main characteristic of experimentalist governance. Governance in the EU combines elements of hierarchy, networks, competition, and negotiations, which, however, gives a picture of collective action. In the case of a common market, governance in the EU takes the form of a hierarchy because it is just an area transferred to the control of the European Commission, and the law adopted in this area stands above national law. Thus, actions were taken at the EU level, even if the agenda is set by collective action, have a hierarchical effect in the political system (Benz, 2009, pp. 29-30). Some authors note that regulatory activities are undertaken by the European Union structure the space in which political processes occur in a vertical dimension, i.e. between supranational and national participants. Where the processes of liberalization and privatization of public services occur, there is also increased activity in the area of new regulations, which, however, does not translate into an increase in the position of the European Union. New supranational institutions do not follow new regulations; there is also no process of expanding the competencies of existing institutions (Grande, Hartenberger, 2009, pp. 199-200). The emergence of a regulatory regime means the existence of participants, procedures, instruments, norms, and principles that affect the process and effect of public regulation in a specific sector (Grande, Hartenberger, 2009, p. 206). Regulatory regimes can thus be considered in two dimensions, the first of which refers to the degree of concentration or dispersion of regulatory competencies, while the second dimension is characterized by the forms of interaction between participating parties. In the case of European space policy, the concentration of competencies in this area is residual, which results from the important role of the European Space Agency as well as from institutional tenders taking place between the Commission and the European Parliament. Also, European space policy has a cross-sectoral dimension, and thus it is impossible to place decision-making processes in one place.

The European Commission is the most important EU actor interested in the political transformation of the European Union's political system towards governance. The strength of the Commission is not because it is an institution isolated from the Member States that do not influence it. The advantage of the Commission is related to the fact that it is "an institution integrated in the process of information exchange, negotiations and tenders, which ultimately leads to a into decision by the Council." The relatively large advantage in the EU's political system makes the Commission a very active institution when it comes to redefining the borders of the European political space, in which it finds two types of allies: subnational participants (Słomczyńska, 2013) and private actors operating on a European and global scale (Kohler-Koch, 1999, p. 19). However, while subnational participants, regions, municipalities, or Länder see the Commission as support in clashing with the government and national interests of lo- 
cal or regional communities, the logic of the second group is different. The second of the indicated groups, correctly reading in which arena should primarily play economic interests in the European Union, is guided by the economic motive, pursuing the interests of dispersed shareholding. This means that the shifting of the borders of the political space, as well as the transformation of the organization of the political actor, which is the EU, is perceived by this group as a tool, and not as an idea as in the case of other actors involved in this process. However, when considering participants of governance processes as a constellation, it should be noted that there is no single motive that would determine the adoption of a specific shape of the proposed policy. Also, when public policies and the provision of public goods are involved, where the potential profits with EU support are potentially high, both parties (private and public participants) must make concessions.

However, with regard to the European space policy, the relations between the indicated two groups do not appear in the "pure" form and there is a specific governance model, whose logic is defined by several elements. The first is the nature of the ownership of companies acting as main partners and initiating or supporting the process of creating an agenda. In this case, the focus should be on the ownership structure of contractor companies winning tenders for ESA that are still in government hands or are supported by government contracts. However, it should be borne in mind that limiting the analysis only to the perspective of the impact of large companies dominating the sector is simplified and insufficient.

The second element is limiting the governance area to the supranational and national arena, which would mean that the governments of the Member States will not introduce regulations regarding space policy in their legal systems, as this is within the competence of the Union. However, this is not the case and research and space projects are defined at the national level, where the EU is only an entity supporting development by funding research programs.

Influence, as a research category, means the ability of an actor to shape a political decision in accordance with his preferences, and in the EU system, such a possibility can be considered in terms of remuneration for supplying specific goods to the system. However, supplying goods to the system (i.e. information) does not mean the possibility of influence, but only performing the role of an expert and legitimizing EU decisions. This is the case for civil society groups receiving financial support from the European Commission. As Mahoney and Beckstrand point out, interest groups that promote civil society, democracy, citizen involvement, and intercultural exchange receive more funding compared to other groups. Moreover, financial support is clear when it comes to being involved at the European level and thus providing legitimacy directly to the European public sector. The same remark applies to interest groups derived from so-called old Europe (Mahoney, Beckstrand, 2011).

Governance in the EU is not only determined by the features of the political system, which, even if it is characterized by a partial democratic deficit, is also determined by how individual participants perceive the rules governing it (Kohler-Koch, 1999, p. 17). Vincent-Jones points out that the most difficult task for modern government is to maximally meet the normative expectations of participants in collective actions(VincentJones, 2013, p. 218). In his opinion, the implementation of this task is possible on 
the assumption that both markets and bureaucracy can fail, and thus the actions of governments do not always bring the expected results. Looking from an economic/ institutional perspective, the effectiveness of bureaucracy becomes important, and thus to what extent "normative expectations" can be met at the lowest cost. The pragmatic approach allows for experimental governance, within the limits of the permissible implementation of "normative expectations." As part of normative expectations, it is also important to consider governance in democratic/deliberative terms, as exemplified by the open method of coordination or the inclusion of representatives of civil society in consultation on specific solutions proposed by the EU administration (Vincent-Jones, 2013, pp. 218-219). Vincent-Jones also emphasizes that the contemporary approach to governance should not be based on achieving a predetermined goal, because it means being connected with one concept of task implementation. Thus, decision-makers should reap as much as possible from the extensive knowledge and information resources, as "consumers" of government decisions regarding public services provide invaluable knowledge not only regarding the effectiveness and purposefulness of actions taken (Vincent-Jones, 2013, p. 221).

\section{Non-traditional policy - non-traditional mode of governance}

However, is European space policy an example of the EU taking over competence in matters previously belonging to the Member States? Maybe it is rather a platform thanks to which some member states, having no possibility to finance projects in the field of space policy, referring to carrier slogans, reached for EU resources. While most authors formulate the thesis that European Union public policies are the result of a gradual increase of changes and the evolution of the EU position, it should be pointed out that in many cases the shift in public policy was the result of groundbreaking changes that took place without the participation of EU institutions or were derivative changes taking place in the Member States. This approach corresponds to the suggestions of Baumgartner and Jones, who, analyzing the American political system, stated that changes in public policies are characterized by chaotic and random nature, rather than assumed growth and gradual change (Baumgartner, Jones, 2009, p. xvii). The system is stable, but it reaches a punctuated equilibrium, in which pre-existing solutions and decision-making processes lose their importance and a new agenda is introduced in their place. Baumgartner and Jones note that changes in the system that result in adopting a particular policy are in many cases a derivative of sudden events that have enabled the emergence of a new agenda. This contradicts the same assumption that political processes are of increasing nature when building the agenda is stretched in time. The aforementioned assumption is associated with an idealistic approach to political reality and exclusion from the analysis of the role of groundbreaking events, which in the eyes of many researchers are symbolic, but do not affect the nature of the agenda (Baumgartner, Jones, 2009, p. 10).

The existing governance model in the European Union in the simplest form can be analyzed using a three-element approach. It should be emphasized that this model, proposed by Adrienne Heritier, addresses the issue where the role of private participants is 
important, who are increasingly influencing the shape and scope of policies taken. This assumption indicates that currently there are no strictly public policies since private actors are always involved in them, even when it concerns matters crucial to the existence of the state, such as public security or defense. This approach assumes that today (1) private actors are involved in the policy formulation process; (2) governance is still based on public actors; (3) governance is based on legislation to a lesser extent (Héritier, 2002, p. 186). This approach assumes the need to create agencies based on regulatory activities. At the same time, the concept of governance and governance is being expanded as the formal and actual ability of private or public actors to define what public goods are and to shape the social, economic, and political processes through which these goods are delivered (Knill, Lehmkuhl, 2002, p. 86). Although in the above definition private and state participants are equal, Knill and Lehmkuhl emphasize that governments still have significant resources that other participants do not have, able to shape governance structures and also to determine preferred policies at the expense of others. At the same time, the influence of private actors can also have a different scale, which means that the relations between private and public participants should be considered as a strategic constellation. This constellation varies depending on the problem under consideration, the degree of convergence between the problem structure and existing regulatory structures, and the institutional context (Knill, Lehmkuhl, 2002, p. 87).

How the delivery of public goods will be determined is largely due to the nature of the relationships between constellation participants, which according to the aforementioned authors can take three forms: coordination, agreement, and withdrawal from the constellation. At the same time, with the three forms of constellation functioning, specific problems arise related to the interests of the participants involved in them, as well as the relative potential of the other constellation members. In the case of coordination, a problem arises when there is agreement on the provision of goods of public access, and agreement has been reached as to the need for a regulatory solution. The problem is, however, what type of solution it should be. In the case of agreement, the problem is related to the lack of agreement as to the need for regulation. The last type refers to the willingness of private participants to take actions that allow them to use resources without costs.

Based on two variables, i.e. the ability to manage by public actors and the ability to manage by private participants, Knill and Lehmkuhl distinguish four possible scenarios of regulatory behavior. The first is based on the high ability of public participants to impose regulatory solutions, while private participants have a low degree of regulatory capacity. This results in the appearance of interventionist regulations, where a public participant, thanks to his strong position, can cause public goods to appear. It should be emphasized, however, as also noted by the above-mentioned authors, that there is a tendency to change the place of government in the market structure and the government does not intervene to provide public goods, but intervenes to enable their delivery (Knill, Lehmkuhl, 2002, p. 93). The second of the ideal types of relationships between public and private actors occurs when both parties can equally influence the system, which results in the appearance of "regulated self-regulation" solutions in the form of private-public partnership (PPP). This solution, however, still promotes public 
participants who can delegate some of their powers to the private sector under the principal-agent model. In this solution, both public and private parties are responsible for providing public goods, but in the case of European space policy, it is an example of the failure of PPP solutions (Mörth, 2007; Nardon, 2009) such as Joint Enterprise Galileo (Europejski Trybunał Obrachunkowy, 2009, p. 17). This does not mean, however, that such solutions are not effectively implemented at the level of Member States under national space policies. An example would be the cooperation of the German government with the German space industry under the TerraSAR-X program.

The third type of regulation appears when, due to the low governance capacity of public participants, it coincides with the high capabilities of the private sector, which in the extreme form leads to the situation where the private sector itself sets regulatory principles and standards as is the case with the International Standards Organization (Büthe, Mattli, 2011). In the background, however, the economic imperative is always visible, and the allegedly supplied public goods serve as a tool to realize economic interests. This also applies to space exploration activities and ISO standards. The last type of regulation occurs when the ability and will to provide public goods by public and private participants is limited. In the case of the second group, this approach is justified because the cost of providing public goods has no economic justification compared to possible profits. The inability to provide public goods to the system may result from several reasons, indicated in another part of this work, but the most important in this case will be the occasional overlap between private and public interests, which may take the form of interference regulation. This means that the attempts made by both sides of the constellation can interfere with each other, and if we assume, as above, that actors do not publicly deliver goods but allow them to deliver, then the public side will play a negative role.

The emergence of new forms of governance in the European Union does not mean that these changes will continue at the same time in all EU policies. This is, first and foremost, due to economic considerations, and the issue of internal and external security remains an important factor since in these areas the full sovereignty of the Member States is an obstacle in over-widening the concept of experimentalist governance (Diedrichs, Reiners, Wessels, 2011b, pp. 9-10). Referring to the experimental concepts of EU governance, it is worth emphasizing that the development of European space policy in its current shape coincided with changes in the logic of the functioning of the European Union, where the traditional method of community integration has been supplemented or replaced by other methods, such as the open method of coordination. In addition to the European Commission, responsible for the agenda-setting, the European Parliament has joined the group of entities that can shape the scope of European policy to a much broader extent. This also applied to space policy, and the European Parliament was the first institution to recognize in 1979 the need for space policy to be created and developed. Some authors say, however, that the European Parliament was "essentially absent in the early years of European Space Policy" (Sigalas, 2012, p. 115), apart from a series of resolutions and reports calling on the Commission to take action with ESA to create a European Space Policy. The traditional method of European integration is based on the transfer of prerogatives from the national level to the level of the European Union in the hands of the Commission, which has a monopoly 
on setting the direction and goal of undertaken actions (agenda-setting). Giandomenico Majone notes, however, that this type of integration is gradually disappearing, we are currently experiencing the phenomenon of delegating competencies in a different direction (Majone, 2009, p. 179). Thus, the Commission, as an institutional entity, undertook the task of introducing experimentalist governance of most European public policies, redefining the concept of power, hierarchy, and subordination.

The starting point for research on relations between the principal and agent is the answer to the question of why it was decided to transfer competencies to agents and agencies (Pollack, 1997). According to Majone, the reasons for delegating competencies should be seen, first of all, in the pursuit of reducing the costs of making decisions, taking advantage of the privilege provided by knowledge about the costs of operating the executive. In other words, the more expensive the decision-making process becomes, the greater the pressure and the will to move the decision-making center to another place. The second premise is the will to maintain the credibility of long-term commitments. These two conditions mustn't operate in parallel, which means that we are dealing with two types of principal-agent relationships that take the form of agency or fiduciary (Majone, 2009, p. 180). In the first of these forms, the main goal is to reduce the costs of making decisions, which means that the agent can pursue other goals than the delegating entity, which is associated with the so-called bureaucratic drift. Even if delegation control mechanisms exist, but they are not used to the full extent, there may be a situation where the policy adopted and the planned objectives differ from the results achieved. If the main purpose of the delegation is the credibility of the policy adopted, there is a problem of the agents' independence as to the scope of actions taken, as well as the degree of credibility of the policy.

The delegation of powers by political entities, according to Epstein and O'Halloran, most often takes place for three reasons. In the first case, the political entity balances the potential gains and costs incurred in making the decision, and when the gains are marginal, it decides to delegate powers. The second situation is to position yourself as a conciliator when the parties' regulations introduced by the administration are unsatisfactory and the political entity can intervene, thereby building its legitimacy to make decisions. In an extreme case, a political entity may use an agent as a "bogey" against society, which, acting as a depoliticized entity, will be presented as an impartial contractor based on expert knowledge (Epstein, O'Halloran, 1999, pp. 30-31). The delegation of powers may also result from the belief in the effectiveness of the so-called regulatory lottery, i.e. a situation in which disagreement over the method of solving the problem results in a delegation to the agency. Thus, the uncertainty of the regulatory process leads to determining effects in the future, and the delegation of powers is intended to unblock the blocked potential. At the same time, it allows shifting responsibility and seemingly depoliticizing regulations, hence the European Union's response to the democratic deficit is precisely the creation of new agencies, where there is no normative basis for seeking democratic legitimacy of expert actions. It is also a form of "experimental governance" which, according to some authors, gives the possibility of freedom to achieve the set goals under a widely accepted consensus. The price of freedom of action and autonomy in the broad sense is regular reporting of results based on criteria adopted by senior decision-makers. Also, goals, policies, 
and procedures are reviewed regularly and new participants have been added (Sabel, Zeitlin, 2010, p. 3). This approach assumes the existence of a hierarchy, a power that defines the criteria for review, but which also catalyzes new governance concepts. This is only possible if it is accepted that institutions and governance in the EU are subject to the logic of governance with networks (rather than networks), which translates into cooperation and weakens the omnipresent Commission power (Lehmkuhl, 2009, p. 118). At the same time, it should be emphasized that thanks to the existence of the EU official body, the key EU institutions are relatively well separated from the world of politics and decisions taken at the supranational level, which protects key EU institutions against political turbulences (Sabel, Zeitlin, 2010, p. 1).

Experimentalist governance occurs when two variables are shaping the boundary conditions for decision making. The first variable is strategic uncertainty, which means you need to know what your goals are and how you can achieve them. The second variable is a multipolar or polyarchic distribution of power in the system, where it is impossible to impose own solutions without taking into account the attitudes and preferences of other entities. Because in the case of the European Union the systems polyarchy and uncertainty about the possibility of action are the dominant features, according to Sabel and Zeitlin, this creates a favorable environment for the diffusion of experimentalist governance (Sabel, Zeitlin, 2010, p. 10). However, two gaps in the concept of Sabel and Zeitlin should be pointed out. First, the assumption about the systems polyarchy is not entirely correct, because the only entity that always remains at the center of the decision is the Commission, which has the power to start the process of creating an experimentalist governance system, and the delegation of powers to the agency is not part of primary law. Thus, the power of deregulation and re-regulation remains at the level of the Commission. The second problem is related to the policy of bargains, also institutional. The consent for experimentalist governance is obtained thanks to the promise of offside payments, i.e. acceptance of experimentalist governance does not result from the strength of the Commissions arguments, but from possible budget shifts, what the Member States are interested in, or increased participation in the decision-making process, what Parliament is interested in. However, not always experimentalist governance results in direct budget changes, and in some cases, the decision on new policies explicitly includes a reservation as to the inability to increase the budget.

Trying to answer the question about why the experimental concepts of EU governance have gained importance, one should refer to political processes taking place in the long term and groundbreaking events from defining the interests of the European Union and the Member States. According to Adrienne Heritier and Dirk Lehmkuhl, the tendency to search for new methods of governance is due to four reasons directly related to concepts such as deregulation and liberalization on the one hand, and changes in the Union itself resulting from enlargement by the new Member States and thus the need to face with challenges of a much wider territorial scale. The first reason indicated is the need for expert knowledge, which the European Commission does not have when it comes to very complex problems related to market integration. Hence, when a technical problem arises that requires a large amount of time to be devoted to expert knowledge is necessary to maintain the flexibility of the decision-making 
process and the ability to respond to changes in a short time. The second prerequisite for introducing new forms of governance are stopping the legislative process by the industrial lobby, which could threaten the interests pursued in individual sectors while declaring self-regulatory steps under the guidelines of the European Union. However, as indicated elsewhere in this job, the goal of private actors is to maximize profits, while the goal of public actors is the safety and well-being of EU residents. This means that despite declarations from the industrial lobby, companies operating on the European market are generally not willing to undertake joint actions, which in effect leads to pressure by the Commission using the threat of introducing legislation. The third condition is based on the rational choice approach, when the Commission, fearing resistance from the Member States to introduce legislation by the Community method, uses new governance methods, treating it as the second option. The fourth condition is related to the will to improve the implementation of adopted legislation (Héritier, Lehmkuhl, 2011, pp. 54-57).

However, experimentalist governance, as a promising concept of change and governance in the EU, should also be considered from an institutional perspective and of progressing Europeanization, Richardson notes that the Commission, like every institution, is a bureaucratic structure oriented towards the pursuit of its interests, in which at the same time there are specific ideas, and the most important of them is the Europeanization (Richardson, 2012, p. 340). It also means that concepts and policies referring to Europe and deepening integration in another area are much more likely to appear on the Commission's agenda. Some authors point out that we are dealing with the specific culture of the Commission, which revolves around the EU's teleological vision, which sees deeper integration as a means to achieve broader political goals (Ellinas, Suleiman, 2011, p. 941). According to Falk Daviter, few decisions taken by the Commission can be qualified as purely political or bureaucratic, and the organizational structure of the Commission is also based on this logic, which means that individual commissioners and their political cabinet clash with the administrative part of the Commission. In addition, Commissioners must also take into account the interests of the entire Commission and the area for which they are directly responsible. There is also little evidence that the other institutions of the Union operated on a different logic, where political and national interests clash with bureaucratic interests (Daviter, 2011, pp. 11-12).

To what extent can Europeanization be used to analyze European space policy? If one analyzes the premises that led to the creation of the European space policy and its inclusion in the Treaty, one can put forward a thesis, space cooperation in Europe is ahead of the process, which is referred to as Europeanization or "the emergence and development of separate governance structures at European level" (Risse, Cowles, Caporaso, 2001, p. 3). The process of building ESA institutional structures was parallel to the development of the Communities and was certainly governed by the same factors as in the case of decisions taken by individual Member States belonging to the Community and then to the European Union. These include the Cold War rivalry, the conviction that it is necessary to build a strong European position, but also a very clear promotion of the common European market defending itself against American competition. 
The question is whether the European space policy could exist without the European Space Agency. The answer is no because it is the European Space Agency that has the necessary resources to implement European projects in space policy. In turn, could the European Space Agency, based on resources and declarations of participating countries, build programs like Galileo or GNSS. Also, in this case, the answer must be in the negative, since the decision to establish cooperation between the EU and ESA resulted from the need to ensure continuous funding for programs that exceeded the financial capacity of participating countries. Thus, the rapprochement between ESA and the EU was the result of a natural process of matching mutual requirements, and European space policy is a complement to building the overall image of the EU as a global actor while underlining the correlation between the common market and the need to include a set of EU public policies and space policy. As Beate Kohler-Koch points out, among other things, the logic of the expansion of European integration has been included in the treaty, as the Community may take action if it is necessary to further develop the common market (Kohler-Koch, 1996, p. 174). This also applies to European space policy and the first justifications for the need to extend the area of Community interest to space exploration were directly related to the concept of building trans-European networks, where European space resources were to be one of the instruments for building a common market. Contrary to opinions that common market rules have limited state involvement in the market and thus public aid for private companies has become impossible, governments of large countries have skillfully adapted their strategies of involvement in the industry, making it more effective than those in which there are problems related to inefficient industrial sectors or backward regions. Strategies for engaging States, however, vary considerably, which may mean that delegating formal powers does not necessarily mean losing the ability to shape policy at the state level. Kohler-Koch suggests that in the face of restrictions and regulations introduced by the EU in the common market, countries have abandoned protectionism and unproductive competition (Kohler-Koch, 1996, pp. 178-179). This is also indicated by studies carried out after the enlargement of new countries in 2004 (Blauberger, 2009). However, the most important institutional innovation of the European Union, namely the Single Market program, has not been tested in experimentalist governance, which is due to the lack of political demands for increased democratization. The lack of experimentalist governance i.e. attempts to get out of the situation and solve the problem is also a derivative of the technical approach to the single market issue, where economic issues have been deprived of political context, and the narrative combining the pursuit of an excellent market with the promise of economic development has effectively eliminated doubts and alternative solutions. However, also the single market is not free from the concept of experimentalist governance, and this applies to ways of shifting transaction costs to adapt the market from the governments of the Member States in the negotiation phase at the EU level to the level of implementation(Schmidt, 2009, p. 134). The new market approach also means transferring regulatory and deregulation competencies to agencies that, when dealing with technical issues, have taken over technical tasks from the Commission and seemingly de-politicized market activities by creating, like regulatory private entities, rules defining the practice of the functioning of the single market (Nicolaïdis, Egan, 2001; Egan, 2009, p. 169). 
Experimentalist governance is only allowed if it is carried out in accordance with procedures and when a clear purpose of the actions taken, rules for assessing effectiveness, monitoring progress, and how methods for drawing conclusions from failures that can arise are indicated (Vincent-Jones, 2013, p. 223). The conflict between the contractual approach to public policies and trust and cooperation, as concepts building society, leads to a situation in which contracts and agreements become detailed to the extent that the parties to the agreement are worried that the contract may be unfavorable until the last moment. This applies both to the relationship between the citizen and the state, as well as relations going beyond the state borders, where goods delivered on a global level, contrary to market concepts, disrupt existing power relations.

Combining the postulates concerning the progressing Europeanization and the emergence of experimental forms of managing European integration, it can be argued that the emergence of the European space policy is one of the elements of the concept of the "treaty ladder," which assumes that in subsequent treaties the EU competencies are expanding and the design of Community law is evolving. The transition from legal assumptions to political decisions is a pragmatic action, and accepted methods of making decisions are expanded with a new solution, but, as some authors believe, eventually lead to a supranational decision-making model (Wessels, 2005, p. 17; Diedrichs, Reiners, Wessels, 2011b, pp. 16-17). Thus, experimentalist governance and at the same time strengthening cooperation and expanding with new policies are components of this process itself, which is the pursuit of supranational solutions controlled by the Commission. At the same time, with the extension of EU competencies, the process of communitarisation of policies is becoming increasingly complicated, and the Member States are becoming more and more open to new governance. This search for a third path between the supranational concept and the maintenance of state competences is a side effect of the tender between participants in political processes. The aim of state activities is not, as some authors believe, blocking changes, but an attempt to establish the rules of a new game, where the win is to maintain control over political processes and gain experience, while the longterm goal is to adopt the Community method.

Experimentalist governance methods in the European Union, therefore, have a growing rather than a revolutionary characteristic of changes, and because these methods appear in different areas of EU activity with varying degrees of intensity, it results in differentiation processes. As a result, instead of a transparent decision architecture, there is a complex and constantly evolving hybrid governance structure. Nevertheless, such evolution and experimentalism in rare cases relate to traditional Community policies, which may suggest that the goal is not to change the way of governing, but to achieve a specific configuration of power (Diedrichs, Reiners, Wessels, 2011b, p. 18). The "real game" is about who and how will establish control over the principles of redefining EU policies so that it corresponds to the preferences of political entities, which ultimately leads to formalization in the form of primary law (Diedrichs, Reiners, Wessels, 2011a, pp. 25-26). Experimental ways of governance, according to some authors, are a transitional structure, a way of approaching the Community method, and not the final form of decision making. Thus, adopting a spillover approach 
and the assumption that new forms of governance will be transferred to other areas of EU policies is not appropriate, as such processes may occur, which, however, will not translate into a radical change in the way decisions are made (Diedrichs, Reiners, Wessels, 2011a, p. 46). In other words, the change that results from adopting experimental forms of governance is "an integral part of the European integration process," which to some extent maintains the influence of states on the progress of European integration, but does not fundamentally undermine the direction of this process. It also slightly affects the institutional balance, and certainly does not change the position of the Commission determining the scope of possible changes and the moment of their implementation. It cannot be ruled out that innovative governance will be supported by countries trying to reach a consensus, and by including new actors and new ways of deciding this goal may seem easier to achieve.

\section{Conclusion}

For the EU, as an international actor, the current regime of space affairs, should be redrafted, to fully reflects European presence in space and the power of the European market. The congruence of two features - the presence of the EU in space, but also as a formal participant in the drafting of the Code of Conduct of Space, and the experimentalist mode of governance in space policy, promoted by the EU, raises the presumption of a causal relationship between EU internal dynamics and contemporary architecture of space regime, coined as experimentalist governance. Such experimentalist governance reflects the EU's contribution to the work of multilateral bodies such as the OECD or ISO. Some authors suggest that space governance shall be shaped by consensus, and the Montreal Declaration can be one of the possible solutions to achieve such a goal). However, with states and private actors, the EU has been of the most active actors in space governance, and the EU's unilateral decision to reshape the market for space services with Copernicus and Galileo allows to extend internal experimentalist procedures. Last and finally, European space assets, offered globally, not only challenge the economy, but also challenge the logic of political power with a new type of regulations over locational, operational, and interactional mobility That kind of governance gives material and physical meaning to EU experimentalist governance in space; the capacity to exert its effects beyond European borders and to produce normative outcomes. When experimentalism posits the setting of broad framework goals as a way of reaching initial consensus amongst it combines with an emphasis on learning from practice and the knowledge and information generated by different stakeholders. In the area of space policy, the division of responsibility between national governments and EU institutions has been hammered out in terms of EU regulations, and member states' national space policies as well as relations with the European Space Agency. All this has forced the EU to invent new institutions and methods of coordination between EU institutions, member states, private actors, and various external stakeholders.

The challenge of this new role in space affairs is to find methods that will allow us to build European capacities at the global level and support long term cooperation 
between EU member states. Space policy is a clear example of an area where experimentalist governance has been extended beyond the EU's borders, and it is an effect of the highly transnational character of space activities. This makes the EU dependent on close cooperation with other international organizations such as the European Telecommunications Standards Institute (ETSI), the European Conference of Postal and Telecommunications Administrations (CEPT), the EUTELSAT, European Telecommunications Satellite Organization), the European Organization for the Exploitation of Meteorological Satellites (EUMETSAT), World Meteorological Organization, also regional such Asia-Pacific Space Cooperation Organization (APSCO) and the AsiaPacific Regional Space Agency Forum (APRSAF), but first and foremost with other spacefaring powers (Klabbers, Trommer, 2014). As of 2019 EU space capacities are still limited and constrained by various factors such as lack of Space Surveillance and Tracking system (SST) or inability to be a member of space treaties and conventions. Nevertheless, space and space systems are strategic and fully global resources, which in comparison to other available EU resources are unique and irreplaceable. Thus, European policy implemented in this dimension both requires a new approach on the part of the EU and draws on many years of experience of other European policies. Space resources and systems serve the various goals of the European Union and the Member States in the social, economic, and security area, e.g. in the areas of meteorology, navigation, positioning, air, and sea traffic control, agriculture and farming, humanitarian operations and responding to natural disasters, national security and border controls. Space systems also stimulate growth and innovation, as the space industry, and space exploitation require creating high-skilled jobs (Petroni, Santini, 2012), producing and selling innovative services, creating market opportunities in other industrial sectors and the need for active support for scientific research All three areas have to be analyzed from the perspective of experimentalist governance, where new standards, procedures, and regulations arrange modalities for participation and contribution to space policy.

\section{Bibliography}

Baumgartner F. R., Jones B. D. (2009), Agendas and instability in American politics, 2nd ed., University of Chicago Press, Chicago.

Benz A. (2009), Combined Modes of Governance in EU Policymaking, in: Innovative governance in the European Union: the politics of multilevel policymaking, eds. I. Tömmel, A. Verdun, Lynne Rienner Publishers, Boulder, pp. 27-44.

Blauberger M. (2009), Compliance with rules of negative integration: European state aid control in the new member states, "Journal of European Public Policy", 16(7), 1030-1046, http:// dx.doi.org/10.1080/13501760903226799.

Büthe T., Mattli W. (2011), The new global rulers: the privatization of regulation in the world economy, Princeton University Press, Princeton, N.J.

Daviter F. (2011), Policy framing in the European Union, Palgrave Macmillan, Basingstoke-New York.

Diedrichs U., Reiners W, Wessels W. (2011a), New Modes of Governance: Policy Developments and the Hidden Step of EU Integration, in: New Modes of Governance in Europe governing 
in the shadow of hierarchy, eds. A. Héritier, M. Rhodes, Palgrave Macmillan, Basingstoke, pp. 19-47.

Diedrichs U., Reiners W., Wessels W. (2011b), The dynamics of change in EU governance, in: The dynamics of change in EU governance, eds. U. Diedrichs, W. Reiners, W. Wessels, Edward Elgar, Cheltenham, pp. 1-20.

Egan M. (2009), Governing the Single Market: From Private Coordination to Public Regulation, in: Innovative governance in the European Union: the politics of multilevel policymaking, eds. I. Tömmel, A. Verdun, Lynne Rienner Publishers, Boulder, pp. 159-178.

Ellinas A. A., Suleiman E. N. (2011), Supranationalism in a Transnational Bureaucracy: The Case of the European Commission, "JCMS: Journal of Common Market Studies", 49(5), pp. 923-947, http://dx.doi.org/10.1111/j.1468-5965.2010.02164.x.

Epstein D., O'Halloran S. (1999), Delegating powers: a transaction cost politics approach to policy making under separate powers, Cambridge University Press, Cambridge-New York.

European Commission (2016), Space Strategy for Europe, COM(2016) 705.

Europejski Trybunał Obrachunkowy (2009), Zarzadzanie faza rozwoju i walidacji programu Galileo.

Genschel P., Jachtenfuchs M. (2014), Beyond Market Regulation. Analysing the European Integration of Core State Powers, in: Beyond the regulatory polity?: the European integration of core state powers, eds. P. Genschel, M. Jachtenfuchs, Oxford University Press, Oxford, pp. 1-23.

Georgakakis D., Rowell J. (2013), Studying Eurocracy as a Bureaucratic Field, in: The field of Eurocracy: mapping EU actors and professionals, eds. D. Georgakakis, J. Rowell, Palgrave Macmillan, Houndmills-Basingstoke-Hampshire, pp. 1-15.

Grande E., Hartenberger U. (2009), Establishing multilevel governance in the European Union: Regulating public utilities, in: Innovative governance in the European Union: the politics of multilevel policymaking, eds. I. Tömmel, A. Verdun, Lynne Rienner Publishers, Boulder, pp. 199-236.

Héritier A. (2002), New Modes of Governance in Europe: Policy-Making without Legislating?, in: Common goods: reinventing European and international governance, ed. A. Héritier, Rowman \& Littlefield, Lanham, Md, pp. 185-206.

Héritier A., Lehmkuhl D. (2011), Governing in the Shadow of Hierarchy, in: New Modes of Governance in Europe governing in the shadow of hierarchy, eds. A. Héritier, M. Rhodes, Palgrave Macmillan, Basingstoke, pp. 48-74.

Hueglin T. O. (1999), Government, Governance, Governmentality, in: The transformation of governance in the European Union, eds. B. Kohler-Koch, R. Eising, Routledge, London-New York, pp. 249-266.

Kauppi N. (2011), EU Politics, in: Sociology of the European Union, eds. A. Favell, V. Guiraudon, Palgrave Macmillan, Basingstoke-New York, pp. 150-171.

Klabbers J., Trommer S. (2014), Peaceful Coexistence: Normative Pluralism in International Law, in: Normative pluralism and international law: exploring global governance, eds. J. Klabbers, T. Piiparinen, Cambridge University Press, Cambridge-New York, pp. 67-93.

Knill C., Lehmkuhl D. (2002), Governance and Globalization: Conceptualizing the Role of Public and Private Actors, in: Common goods: reinventing European and international governance, ed. A. Héritier, Rowman \& Littlefield, Lanham, pp. 85-104.

Kohler-Koch B. (1996), Catching up with change: The transformation of governance in the European Union, "Journal of European Public Policy", 3(3), pp. 359-380, http://dx.doi. org/10.1080/13501769608407039.

Kohler-Koch B. (1996), The Strenght of Weakness: The Transformation of Governance in the EU, in: The future of the nation state: essays on cultural pluralism and political integration, eds.

S. Gustavsson, L. Lewin, Nerenius \& Santerus, Stockholm, pp. 169-210. 
Kohler-Koch B. (1999), The evolution and transformation of European governance, in: The transformation of governance in the European Union, eds. B. Kohler-Koch, R. Eising, Routledge, London-New York, pp. 14-35.

Lehmkuhl D. (2009), Cooperation and Hierarchy in EU Competition Policy, in: Innovative governance in the European Union: the politics of multilevel policymaking, eds. I. Tömmel, A. Verdun, Lynne Rienner Publishers, Boulder, pp. 103-119.

Leuffen D., Rittberger B., Schimmelfennig F. (2012), Differentiated integration: explaining variation in the European Union, Palgrave Macmillan, Basingstoke.

Madders K. (1997), A new force at a new frontier: Europe's development in the space field in the light of its main actors, policies, law, and activities from its beginnings up to the present, Cambridge University Press, Cambridge-New York.

Mahoney C., Beckstrand M. J. (2011), Following the Money: European Union Funding of Civil Society Organizations, "JCMS: Journal of Common Market Studies”, 49(6)1339-1361, http:// dx.doi.org/10.1111/j.1468-5965.2011.02197.x.

Majone G. (2009), Europe as the would-be world power: the EU at fifty, Cambridge University Press, Cambridge-New York.

Moravcsik A., Schimmelfennig F. (2009), Liberal Intergovernmentalism, in: European integration theory, eds. A. Wiener, T. Diez, 2nd edn., Oxford University Press, Oxford-New York, pp. 67-87.

Mörth U. (2007), Public and Private Partnerships as Dilemmas between Efficiency and Democratic Accountability: The Case of Galileo, "Journal of European Integration", 29(5)601-617, http://dx.doi.org/10.1080/07036330701694907.

Nardon L. (2009), Galileo and the Issue of Public Funding, in: Yearbook on Space Policy 2007/2008: From Policies to Programmes, eds. K.-U. Schrogl, C. Mathieu, N. Peter, Springer Science \& Business Media, Wien, pp. 125-137.

Nicolaïdis K., Egan M. (2001), Transnational market governance and regional policy externality: why recognize foreign standards?, "Journal of European Public Policy", 8(3)454-473, http:// dx.doi.org/10.1080/13501760110056068.

Petroni G., Santini S. (2012), Innovation and change? The evolution of Europe's small satellite manufacturers, "Space Policy”, 28(1)25-32, http://dx.doi.org/10.1016/j.spacepol.2011.12.008.

Pollack M. A. (1997), Delegation, agency, and agenda setting in the European Community, "International Organization", 51(01)99-134, http://dx.doi.org/10.1162/002081897550311.

Richardson J. (2012), The Onward March of Europeanization: Tectonic Movement and Seismic Events, in: Constructing a policy-making state? policy dynamics in the EU, ed. J. Richardson, Oxford University Press, Oxford, pp. 334-359.

Risse T., Cowles M. G., Caporaso J. (2001), Europeanization and Domestic Change: Introduction, in: Transforming Europe: Europeanization and domestic change, eds. M. G. Cowles, J. A. Caporaso, T. Risse-Kappen, Cornell University Press, Ithaca, N.Y., pp. 1-20.

Sabel C. F., Zeitlin J. (2010), Learning From Difference: The New Architecture of Experimentalist Governance in the EU, in: Experimentalist governance in the European Union: towards a new architecture, eds. C. F. Sabel, J. Zeitlin, Oxford University Press, Oxford, pp. 1-28.

Saurugger S. (2014), Theoretical approaches to European integration, Palgrave Macmillan, Basingstoke.

Schmidt S. K. (2009), Single Market Policies: From Mutual Recognition to Institution Building, in: Innovative governance in the European Union: the politics of multilevel policymaking, eds. I. Tömmel, A. Verdun, Lynne Rienner Publishers, Boulder, pp. 121-138.

Sigalas E. (2012), The role of the European parliament in the development of a European union space policy, “Space Policy”, 28(2)110-117, http://dx.doi.org/10.1016/j.spacepol.2012.02.007. 
Słomczyńska I. (2013), Geneza i rozwój strategii makroregionalnych Unii Europejskiej w kontekście realizacji koncepcji wielopoziomowego sprawowania rządów, „Analizy Natolińskie”, (11).

Tömmel I. (2009), Modes of Governance and the Institutional Structure of the European Union, in: Innovative governance in the European Union: the politics of multilevel policymaking, eds. I. Tömmel, A. Verdun, Lynne Rienner Publishers, Boulder, pp. 9-23.

Vincent-Jones P. (2013), Relational Contract and Social Learning in Hybrid Organization, in: Changing concepts of contract: essays in honour of Ian Macneil, eds. D. Campbell, L. Mulcahy, S. Wheeler, Palgrave Macmillan, Houndmills-Basingstoke-Hampshire, pp. 216-233.

Wallace H. (2001), The Changing Politics of the EU: An Overview, "JCMS: Journal of Common Market Studies”, 39(4)581-594, http://dx.doi.org/10.1111/1468-5965.00322.

Wallace H. (2003), Contrasting Images of European Governance, in: Linking EU and national governance, ed. B. Kohler-Koch, Oxford University Press, Oxford, pp. 1-9.

Wessels W. (2005), Keynote article: the constitutional treaty-three readings from a fusion perspective, "JCMS: Journal of Common Market Studies", 43(s1) 11-36.

Zabusky S. E. (1995), Launching Europe: an ethnography of European cooperation in space science, Princeton University Press, Princeton, N.J.

\section{Summary}

The purpose of the article is to analyze ESP in the context of different modes of governance. Assuming that ESP is a unique and multidimensional product of dynamic political, technological, and social processes and ideas coordinated by the EU, its member states as well as nonmember ones and implemented in an international environment, there are some research questions to be answered. First, is there any particular mode of governance that should be applied to the analysis of ESP implementation? Second, in what way the EU introduced space policy and space assets to the European agenda? Third, how ESP can be framed within the overall process of European integration? A qualitative research approach has been applied as well as theoretic apparatus embedded in European integration studies and political science. The main finding of the article is that the most promising way of governance within ESP is experimentalist governance. The originality of the article results from the application of the newly established experimentalist governance theory to an analysis of the increasingly important segment of EU activity.

Key words: European Union, European Space Policy, governance, experimentalist governance

\section{Zarządzanie europejską polityką kosmiczną}

\section{Streszczenie}

Celem tego artykułu jest analiza EPK w kontekście różnych sposobów zarządzania. Zakładając, że EPK jest unikalnym i wielowymiarowym produktem dynamicznych procesów politycznych, technologicznych i społecznych koordynowanych przez UE, jej państwa członkowskie oraz państwa trzecie i wdrażanych w środowisku międzynarodowym, należy odpowiedzieć na kilka pytań badawczych. Po pierwsze, czy istnieje jakiś szczególny sposób zarządzania, który należy zastosować do analizy implemetacji EPK? Po drugie, w jaki sposób UE wprowadziła politykę kosmiczną i problematykę zasobów kosmicznych do europejskiej agendy? Po trzecie, w jaki sposób EPK można osadzić w kontekście ogólnego procesu integracji europejskiej? $\mathrm{W}$ artykule zastosowano jakościowe podejście badawcze, a także aparat teoretyczny z zakresu 
studiów nad integracją europejską i nauk politycznych. Głównym wnioskiem tego artykułu jest stwierdzenie, że najbardziej obiecującym sposobem zarządzania w EPK jest zarządzanie eksperymentalne. Oryginalność artykułu wynika z zastosowania nowopowstałej teorii eksperymentalnego zarządzania w analizie coraz ważniejszego segmentu działalności UE.

Słowa kluczowe: Unia Europejska, Europejska polityka kosmiczna, zarządzanie, zarządzanie eksperymentalne 